\title{
A ruthless sarcoma of the foot
}

\section{Shikhar Agarwal}

Cleveland Clinic, Cleveland, Ohio, USA

\section{Correspondence to} Dr Shikhar Agarwal, dr.shikhar.agarwal@gmail.com

Accepted 5 February 2015

\section{DESCRIPTION}

A 45-year-old man presented with non-tender soft tissue swelling on the medial aspect of the right foot with pain during dorsiflexion and eversion of the foot. X-ray (figure 1) and MRI (figure 2) of the mass revealed a heterogeneous soft tissue mass arising out of the calcaneal bone. Figure 1 demonstrates the X-ray showing the soft tissue mass in the medial aspect of the right foot along with diffuse osteopenia of the calcaneal bone. Figure 2 demonstrates the MRI corroborating the findings of the $\mathrm{X}$-ray showing a heterogeneous mass arising from the calcaneal bone on the medial aspect of the foot.

Surgical biopsy of the mass was consistent with clear cell sarcoma involving the tendon sheaths. Fluorescence in situ hybridisation demonstrated the presence of an Ewing Sarcoma translocation $[\mathrm{t}(12,22)(\mathrm{q} 13, \mathrm{q} 12)]$, characteristic of clear cell sarcoma. The tumour at presentation was widely

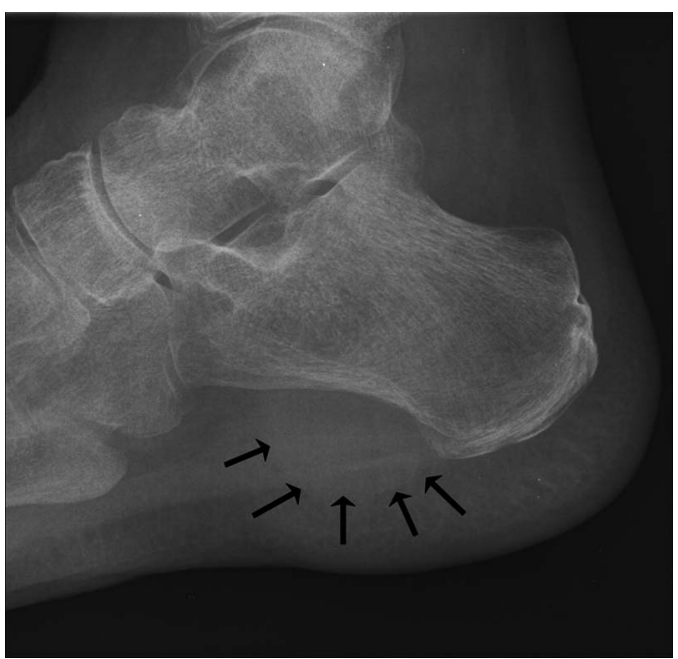

Figure $1 \mathrm{X}$-ray demonstrating the soft tissue mass in the medial aspect of the right foot. Arrow points to the diffuse osteopenia of the calcaneal bone. metastatic involving lungs (figure 3 ) as well as retroperitoneal and inguinal lymph nodes (figure 4). Figure 3 demonstrates CT of the chest (axial, panel A; coronal, panel B) showing prominent hilar lymphadenopathy (white arrows). Figure 4 demonstrates CT of the pelvis demonstrating significant right-sided inguinal lymphadenopathy (white arrow).

Owing to this widespread metastasis, an amputation was not performed, as the disease was thought

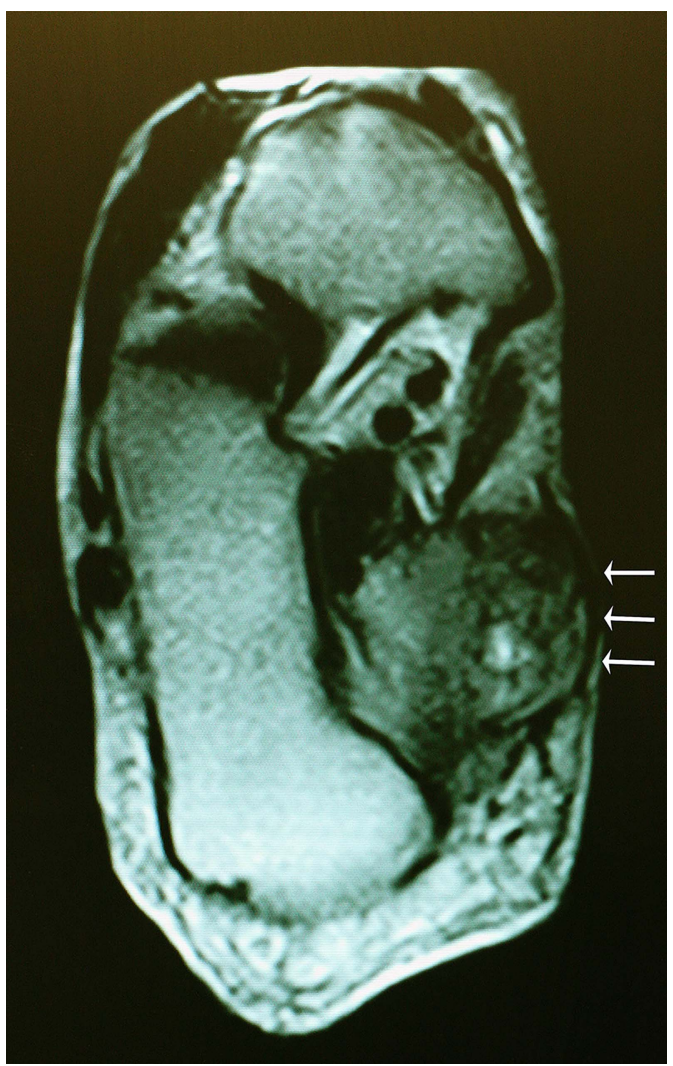

Figure 2 MRI corroborating the findings of the X-ray demonstrating a heterogeneous mass arising from the calcaneal bone on the medial aspect of the foot. 
Figure $3 \mathrm{CT}$ of the chest demonstrating prominent hilar lymphadenopathy (white arrows) (A) Axial section and (B) coronal section.
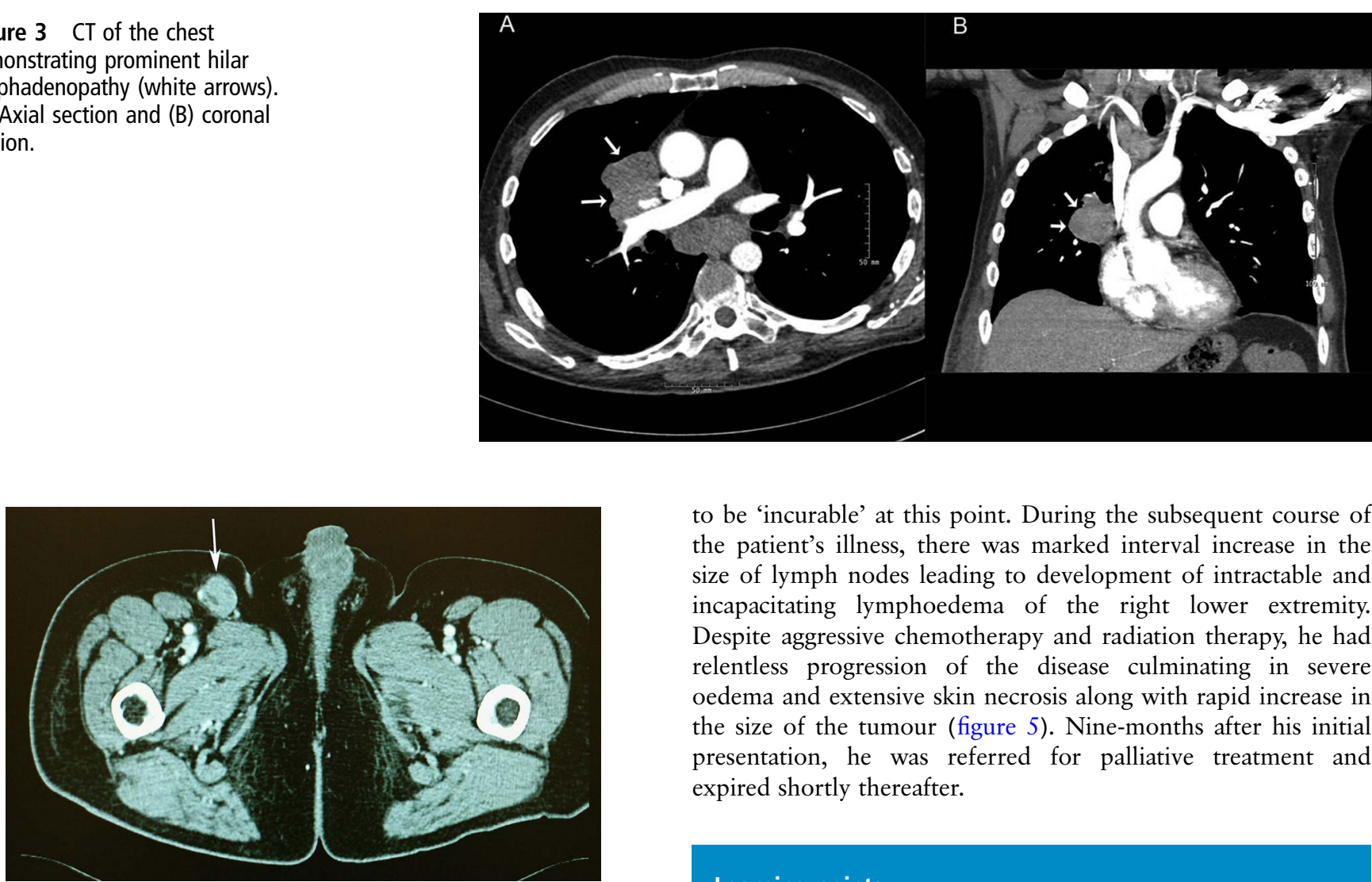

Figure $4 \mathrm{CT}$ of the pelvis demonstrating significant right-sided inguinal lymphadenopathy.

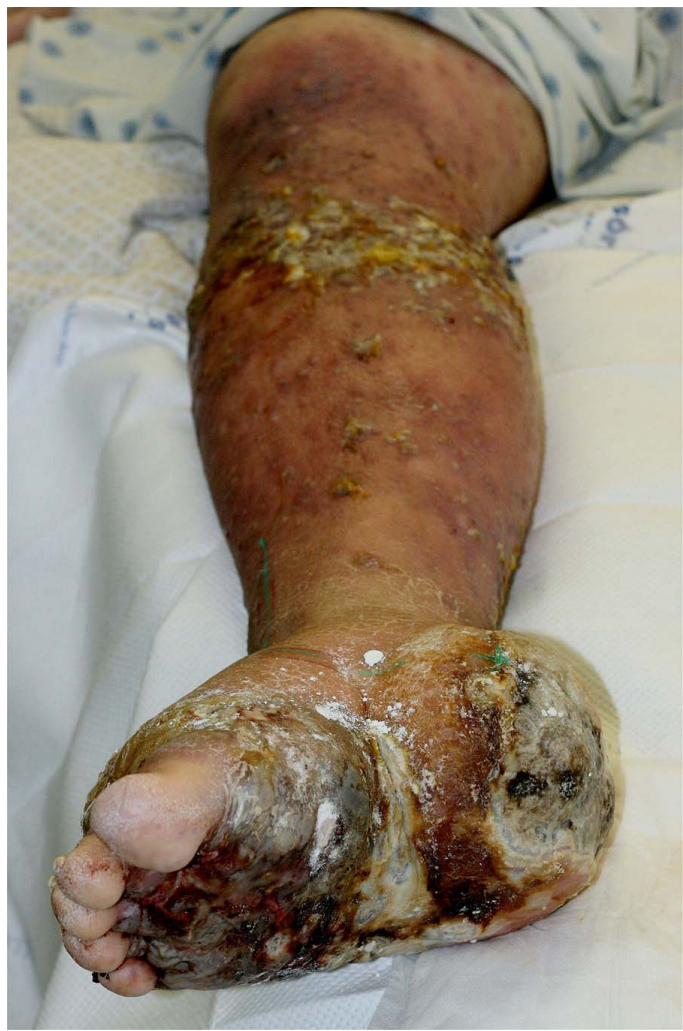

Figure 5 Locally invasive sarcoma with large areas of necrotic skin along with significant lower extremity oedema. to be 'incurable' at this point. During the subsequent course of the patient's illness, there was marked interval increase in the size of lymph nodes leading to development of intractable and incapacitating lymphoedema of the right lower extremity. Despite aggressive chemotherapy and radiation therapy, he had relentless progression of the disease culminating in severe oedema and extensive skin necrosis along with rapid increase in the size of the tumour (figure 5). Nine-months after his initial presentation, he was referred for palliative treatment and expired shortly thereafter.

\section{Learning points}

- Clear cell sarcomas of the bone are exceedingly rare tumours that carry poor prognosis.

- Clear cell sarcomas have a rapid progression and a high metastatic potential and are often widely metastasised at diagnosis.

- Multimodality imaging and immunohistochemistry are vital for diagnosis of clear cell sarcoma.

Competing interests None.

Patient consent Obtained.

Provenance and peer review Not commissioned; externally peer reviewed. 
Copyright 2015 BMJ Publishing Group. All rights reserved. For permission to reuse any of this content visit http://group.bmj.com/group/rights-licensing/permissions.

BMJ Case Report Fellows may re-use this article for personal use and teaching without any further permission.

Become a Fellow of BMJ Case Reports today and you can:

- Submit as many cases as you like

- Enjoy fast sympathetic peer review and rapid publication of accepted articles

- Access all the published articles

- Re-use any of the published material for personal use and teaching without further permission

For information on Institutional Fellowships contact consortiasales@bmjgroup.com

Visit casereports.bmj.com for more articles like this and to become a Fellow 